УДК 338.2

DOI https://doi.org/10.32836/2310-9653-2021-1.15

\author{
В. С. Гнатенко, кандидат економічних наук, \\ науковий співробітник \\ Д3 «Науково-практичний медичний \\ реабілітаційно-діагностичний центр \\ Міністерства охорони здоров'я України»
}

\title{
РОЗВИТОКОСНОВНИХВЕКТОРІВЗАБЕЗПЕЧЕННЯЕКОНОМІЧНОЇБЕЗПЕКИУКРАЇНИ
}

Забезпечення економічної безпеки входить до складу найважливіших функиій держсви, тому ияя проблема ніколи не існувала сама по собі, а завжди була похідною від завдань економічного зростання на кожному ступені розвитку суспільства. Конкретний зміст проблеми економічної безпеки змінюється залежно від сформованих у певний період внутрішніх $і$ зовнішніх умов.

Система забезпечення економічної безпеки країни трунтується на розумінні та реалізації концепції національних економічних інтересів на державному та міжнародному рівнях, метою якої є підтримка збалансованості економіки, захист ї від виливу зовнішніх і внутрішніх загроз, здатність до стабільного розвитку.

Забезпечення прийнятного рівня економічної безпеки визнано в Україні однією з головних стратегічних иілей національної безпеки. Система національних економічних інтересів не статична, вона постійно змінюється під впливом великоі кількості чинників. Під час появи і зникнення, наростання $і$ зменшення загроз економічній безпеиі повинні змінюватися $і$ коригуватися національні економічні інтереси країни.

Економічна безпека є багатогранним, багатоаспектним, системним явищем. Як система вона складається з великої кількості елементів, має ієрархію рівнів організаџії, здатна генерувати в прочесі розвитку нові рівні, водночас новий рівень впливає на попередні рівні, перебудовує їx, у результаті чого система отримує нову иілісність. Система забезпечення економічної безпеки передбачає організачію діяльності держави та суспільства для ухвалення та реалізації рімень із питань національної безпеки з урахуванням конщептуальних, організаційних і ресурсних аспектів формування й ефективного функиіонування системи забезпечення економічної безпеки.

Забезпечення економічної безпеки - ие не тільки гарантія незалежності країни, але й умова стабільності та ефективної життєдіяльності суспільства. Пояснюється ие тим, що економіка є однією з життєво важливих сторін діяльності не тільки держави, а й особистості та суспільства. Поняття національної безпеки не матиме значення без оцінки життєздатності економіки, їі міцності за можливих зовнішніх і внутрішніх загроз. Саме тому забезпечення економічної безпеки - ие найважливіший держсвний пріоритет.

Ключові слова: економічна безпека, національна безпека, загрози, економічний суверенітет, економічний розвиток держави, національні економічні інтереси.

\section{S. Hnatenko. Development of the main vectors for ensuring of the economic security of Ukraine}

Ensuring of the economic security is a part of the most important functions of the state, so this problem has never existed in itself, but has always been derived from the tasks of economic growth at every stage of society. The specific content of the problem of economic security varies depending on the current internal and external conditions.

The country's economic security system is based on understanding and realization of the national economic interests' concept at the national and international levels, which aims to maintain the balance of the economy, protect it from the external and internal threats, and to bolster the ability to sustainable development.

Ensuring of an acceptable level of economic security in Ukraine has been recognized as one of the main strategic goals of the national security. The system of the national economic interests is not static; it changes constantly under the influence of many factors. When threats to economic security appear and disappear, increase and decrease, the national economic interests of the country must be changed and adjusted.

Economic security is a complicated, multifaceted, systemic phenomenon. As a system, it consists of a large number of elements, has a hierarchy of the organization levels, able to generate new levels in the development process, while the new level affects the previous levels, rebuilds them, resulting in a new integrity. The system of economic security involves the organization of the state and society activity to make and implement decisions on national security, taking into account the conceptual, organizational and resource aspects of the formation and effective functioning of the economic security system.

Ensuring of the economic security is not only a guarantee of the country's independence, but also a condition for the stability and efficient functioning of society. This is explained by the fact that the economy is one of the vital aspects of not only the state but also the individual and society. The concept of the national security will not matter without assessing the viability of the economy, its strength in the face of possible external and internal threats. That is why ensuring of the economic security is the most important state priority.

Key words: economic security, national security, threats, economic sovereignty, economic development of the state, national economic interests.

\section{(C) В. С. Гнатенко, 2021}


Постановка проблеми. На сучасному розвитку економіки України вагому роль для економічного становлення відіграє рівень економічної безпеки країни. Ключова мета економічного становлення держави - це не тільки стабільне економічне зростання, а й збільшення зайнятості, забезпечення стабільності грошової системи, зростання рівня добробуту населення. Зважаючи на це, сутність економічної безпеки на державному рівні складається з можливості їі економічної системи протистояти негативному впливу внутрішніх і зовнішніх чинників.

Економічна безпека держави, зі свого боку, являє собою складне поняття, яке відображає велику кількість змінних щодня умов матеріального виробництва, а також внутрішніх і зовнішніх загроз економіці країни.

Сьогодні економічна безпека належить до проблем, які привертають увагу фахівців найрізноманітнішого профілю. Перш за все це пов'язано з тим, що економічна сфера країни є головною, ключовою та домінантною щодо інших видів безпеки країни.

Аналіз останніх досліджень і публікацій. Проблемі побудови ефективної системи забезпечення національної безпеки та економічної безпеки як однієї з головних її складників присвячено роботи таких дослідників, як Д.О. Кошикова [1], В.О. Лазарєва, Я.С. Палешко [2], Н.М. Левченко, Л.В. Антонової [3], Х.О. Мандзіновської [4], В.Л. Поздєєва [5], А.В. Рогового [6], В.В. Сазонова [7], Г.Б. Соколової [8], Є.В. Шпилевської [9], J. Dunning [10], B. Khondker [11], D. McCormick, C. Luftig, J. Cunningham [12] та інших; у них представлено теоретичні основи забезпечення національної безпеки, принципи державного управління національною безпекою, поняття і зміст національних інтересів.

Мета статті - проаналізувати основні вектори забезпечення економічної безпеки держави.

Виклад основного матеріалу. Основу національної безпеки становить економічна безпека, яка, зі свого боку, може бути забезпечена за умови сталого і збалансованого розвитку всіх елементів соціально-економічної системи. Для цього необхідні цивілізовані ринкові відносини, сучасна інфраструктура, високі технології та ефективна організація виробництва, оптимальна галузева структура економіки й раціональна продуктова спеціалізація підприємств, розвинена фінансова система, достатній за обсягом і якісний трудовий та інтелектуальний потенціал. Усі перелічені складники економічного розвитку мають складну організацію й повинні бути збалансовані як за співвідношенням своїх структурних елементів, так і за відношенням до факторів зовнішнього середовища.

Створення та підтримка цих умов у країнах із ринковою економікою вкрай ускладнені внаслідок цілої низки причин ендогенної і екзогенної природи. Ендогенні причини полягають у тому, що в умовах ринкових відносин держава як інститут, що забезпечує централізоване управління соціально-економічною системою, обмежена у своїх можливостях регулювати поведінку багатьох самостійних незалежних суб'єктів господарської діяльності. Оптимальним повинно бути співвідношення механізмів саморозвитку соціально-економічної системи та засобів державного централізованого регулювання. Ці співвідношення змінюються залежно від стану соціально-економічної системи. Наприклад, в умовах глобальної кризи різко зросла потреба у використанні механізмів державного регулювання ринкових відносин.

Неоднозначним є вплив факторів зовнішнього середовища на розвиток національних економік. Світ рухається в напрямку зростання їхньої відкритості. Міжнародний поділ праці є передумовою економічного прогресу. Але для кожної конкретної країни є свої специфічні критерії оптимальних пропорцій у сфері обміну ресурсами та продуктами з іншими країнами, в основі яких також лежить принцип збалансованості. Економіка країни зберігає властивості цілісної системи, яка саморозвивається доти, доки комплексний потенціал внутрішнього середовища істотно перевершує сукупний вплив негативних факторів зовнішнього середовища. У разі порушення цієї пропорції соціально-економічна система втрачає стійкість і виникає загроза ііі руйнування. Ознаки такого негативного розвитку системи не виникають миттєво - вони накопичуються поступово. Це означає, що є резерв часу для реалізації заходів щодо запобігання загрозам. Але ця ж поступовість заважає своєчасному розпізнаванню прийдешньої загрози.

Виникає питання щодо шляхів запобігання загрозам національної безпеці, викликаних різкими порушеннями збалансованості соціально-економічних систем. Відповідь на це запитання могла б містити такі положення:

- теоретичною базою повинні бути науково обгрунтовані знання про основні механізми виникнення економічних дисбалансів і зумовлені ними загрози національній безпеці;

- прикладні аспекти проблеми полягають в організації моніторингу стану і динаміки соціально-економічних систем із метою своєчасного виявлення та діагностики потенційних загроз національній безпеці, зумовлених деструктивними явищами в економіці;

- управління процесом забезпечення збалансованого ефективного розвитку економіки здійснюється на всіх ієрархічних рівнях функціонування національної економіки. Свої специфічні повноваження в цій галузі мають суб’єкти господарської діяльності та інститути влади муніципального, регіонального та державного рівнів;

- кожна група суб'єктів управління розвитком соціально-економічних систем має у своєму розпорядженні свої особливі ресурси та можливості, їхні дії детерміновані специфічними інтересами й цілями, що в кінцевому підсумку призводить до значної розбіжності їхніх орієнтацій на розвиток у короткостроковій і довгостроковій перспективах; 
- насправді ситуація не настільки драматична, оскільки за свою багатовікову історію людство виробило комплекс інструментів, за допомогою яких державна влада прямими і непрямими методами цілком успішно регулює поведінку всіх категорій інституційних одиниць. Такими інструментами є законодавство, силові відомства, система пільг і заохочень, ЗМІ, комплекс морально-етичних цінностей;

- на сучасному етапі позиції державної влади значно ослаблені і продовжують слабшати через такі внутрішні та зовнішні причини, як процес глобалізації, зростання рівня відкритості національних соціально-економічних систем, демократизація суспільних відносин, проникнення інформаційно-комунікаційних технологій в усі сфери життя, наростання фінансової та економічної могутності приватного капіталу, транснаціональних корпорацій. Відбувається дедалі більша інтернаціоналізація всіх сфер суспільного життя. Крім низки позитивних результатів, ці чинники здатні викликати деструктивні зміни в соціально-економічній системі менш розвинених держав;

- концептуальні засади управління збалансованим розвитком соціально-економічної системи повинні спиратися на такі принципи та критерії оптимальності:

1) узгодженість і несуперечність тактичних і стратегічних цілей;

2) використання логіки системного підходу до розв'язання всіх завдань управління;

3) забезпечення гнучкості системи управління в умовах мінливого середовища;

4) забезпечення достатньої кількості та раціональної структури всіх видів матеріальних, трудових і інформаційних ресурсів;

5) зростання рівня економічної культури й довіри до влади за мінімізації рівня конфліктності та кримінальності соціального середовища;

6) гарантії соціальної захищеності всіх верств населення;

7) створення правових, політичних, економічних і соціально-культурних передумов для забезпечення конкурентоспроможності та ефективного функціонування первинної ланки економіки - суб'єктів господарської діяльності;

8) раціональне поєднання прямих і непрямих методів державного регулювання поведінки всіх категорій учасників суспільно-економічних відносин;

9) оптимізація балансу повноважень і відповідальності населення, господарюючих суб'єктів, органів влади, політичних та громадських організації на мікро-, мезо- і макрорівнях;

10) розроблення й використання в практиці управління короткострокових і довгострокових прогнозів розвитку соціально-економічної системи та кон’юнктури зовнішнього середовища.

Зазначені принципи і критерії становлять єдину систему. Це означає, що позитивна роль одного $з$ них може знецінитися або посилитися залежно від стану соціально-економічної системи з позиції інших принципів і критеріїв. Наприклад, використання високотехнологічного обладнання не дасть очікуваного ефекту за браку кадрів працівників відповідної кваліфікації і слабкого менеджменту.

3 метою практичного застосування кожен із зазначених принципів і критеріїв повинен бути представлений розгорнутим переліком числових параметрів у кількісній формі диференційовано за різними категоріями об'єктів управління на різних рівнях управління. Ця система параметрів повинна відповідати загальноприйнятим вимогам узгодженості, порівнянності, достовірності, своєчасності, дотримання яких може бути пов'язано 3 низкою труднощів. Наприклад, через невизначеність механізмів впливу багатьох чинників неможливо з достатньою точністю виміряти силу їхнього впливу. Через високу динамічність соціально-економічних процесів їхні кількісні параметри швидко застарівають і перестають відповідати реальним умовам і станам об'єктів управління. Це стосується як їхніх числових значень, так і самого переліку параметрів.

У сукупності ці параметри можуть утворити описову модель соціально-економічної системи. Така модель може бути статичною або динамічною. Можливий різний ступінь їі наближення до реальних характеристик соціально-економічної системи.

У спрощеному вигляді модель збалансованої соціально-економічної системи можна уявити як схему, на якій позначено структурні елементи системи, процеси, що протікають у ній, і вектори їхніх зв'язків та взаємодій без будь-яких числових індикаторів. В основі таких моделей лежить принцип відтворення логічних зв'язків і співвідношень у соціально-економічній системі.

Більш досконалими є економіко-математичні моделі, що являють собою складний комплекс математичних формул, які відтворюють стан, процеси, результати функціонування соціально-економічної системи. Перевагою таких моделей є використання кількісної міри явищ і процесів. Слабкий їхній бік полягає в застосуванні цілої низки обмежень і умовностей, що ускладнює їх практичне застосування через розбіжності реальності з умовностями моделі. Проте економіко-математичні моделі дають можливість оцінити можливі стани й умови збалансованості соціально-економічної системи в разі реалізації конкретних сценаріїв розвитку.

Практичне використання економіко-математичних моделей розвитку соціально-економічних систем може здійснюватися одним із декількох способів або шляхом певної їх комбінації. Найпростішим і доступним є застосування цих моделей із метою адаптації управлінських рішень до умов, що склалися у внутрішньому й зовнішньому середовищі. Модель допомагає більш правильно оцінювати можливі наслідки тих чи інших управлінських рішень. 
Глибше проникнення в механізми суспільних процесів досягається під час використання математико-економічних моделей із метою активного впливу на розвиток соціально-економічної системи в заданому напрямі. В умовах безперервно мінливих умов внутрішнього і зовнішнього середовища інститути управління повинні мати здатність до гнучкості в питаннях визначення завдань і методів управління за збереження стабільності стратегічних цілей розвитку системи. Проєкти розвитку керованої соціально-економічної системи оформляються у вигляді комплексних програм розвитку регіону, бізнес-планів підприємства, пріоритетних національних програм.

Висновки 3 дослідження і перспективи подальших розвідок у цьому напрямі.

Для забезпечення економічної безпеки необхідно запропонувати належні заходи:

1) розвинути внутрішній ринок держави;

2) підвищити добробут населення;

3) збільшити ефективність управління власністю і в приватному, і в державному секторах;

4) зменшити наявний стан національної економіки на користь орієнтованого на експорт сектору економіки.

Окрім названих вище заходів щодо забезпечення економічної безпеки, для підтримки системи державної економічної безпеки необхідно:

- активізувати дії за всіма тенденціями методологічних розробок, що передбачають створення актуального нормативно-правового простору;

- розробити механізм розв'язання спірних питань і конфліктних ситуацій, що виникають у сфері економіки;

- гарантувати гармонійний розвиток економічних і політичних відносин з іншими країнами;

- зміцнити значення державної влади та збільшити довіру населення до їі інститутів.

\section{Список використаних джерел:}

1. Кошиков Д.О. Поняття та класифікація функцій державної політики у сфері забезпечення економічної безпеки держави. Право і безпека. 2020. № 1 (76). C. 67-73. DOI: https://doi.org/10.32631/pb.2020.1.09.

2. Лазарєв В.О., Палешко Я.С. Економічна безпека держави з урахуванням процесу діджиталізації. Міжнародна та національна безпека: теоретичні і прикладні аспекти : матеріали IV Міжнародної науково-практичної конференції (ДДУВС, 13.03.2020). Дніпро, 2020. С. 155-158.

3. Левченко Н.М., Антонова Л.В. Економічна дипломатія як запорука національної безпеки держави. Державне управління: удосконалення та розвиток. 2020. № 5. URL: http://www.dy.nayka.com.ua.

4. Мандзіновська Х.О. Економічна безпека держави: сутність, складові елементи та проблеми забезпечення. Наукові записки. Scientific papers. 2016. № 2 (53). С. 159-166.

5. Поздеев В.Л. Основные направления обеспечения экономической безопасности государства. Инноваџионное развитие экономики. 2016. № 6-2 (36). С. 270-276.

6. Роговий А.В. Детермінанти забезпечення економічної безпеки держави. Проблеми та перспективи розвитку фінансової системи в сучасних умовах : збірник матеріалів II Міжнародної науково-практичної інтернет-конференції, м. Полтава, 9-10 квітня 2020 р. Полтава : ПУЕТ, 2020. С. 152-154.

7. Сазонов В.В. Зовнішні загрози економічній безпеці держави. Наше право. 2020. № 1. С. 121-126.

8. Соколова Г.Б. Деякі аспекти розвитку цифрової економіки в Україні. Економічний вісник Донбасу. 2018. № 1 (51). С. 92-96.

9. Шпилевская Е.В. Экономическая безопасность страны: угрозы и пути ее обеспечения. Экономические науки. 2016. № 5 (47). С. 188-193.

10. Dunning John H. The eclectic paradigm as an envelope for economic and business theories of MNE activity. International Business Review. 2000. Vol. 9. 163 p.

11. Khondker B.H. Economic Impacts of a Universal Pension in Bangladesh. Pathways' Perspectives on Social Policy, International Development. 2014. Issue № 17. P. 1-6.

12. McCormick David H., Luftig Charles E., Cunningham James M. Economic Might, National Security, and the Future of American Statecraft (Summer 2020). Texas National Security Review. Vol. 3. Issue 3. Autumn 2020. P. 50-75.

\section{References:}

1. Koshikov D.O. (2020), "Ponyattya ta klasyfikatsiya funktsiy derzhavnoyi polityky u sferi zabezpechennya ekonomichnoyi bezpeky derzhavy" ["The concept and classification of functions of state policy in the field of economic security of the state"], journal Pravo i bezpeka [Law and security], vol. 1 (76), pp. 67-73 [Ukraine]

2. Lazaryev V.O. and Paleshko Ya.S. (2020), "Ekonomichna bezpeka derzhavy z urakhuvannyam protsesu didzhytalizatsiyi" ["Economic security of the state taking into account the process of digitalization"], materials of the IV International. science-practice conference Mizhnarodna ta natsionalna bezpeka: teoretychni $i$ prykladni aspekty [International and national security: theoretical and applied aspects], Press DDUVS, Dnipro. pp. 155-158 
3. Levchenko N.M. and Antonova L.V. (2020), "Ekonomichna dyplomatiya yak zaporuka natsionalnoyi bezpeky derzhavy" ["Economic diplomacy as a guarantee of national security"], Electronic scientific journal Derzhavne upravlinnya: udoskonalennya ta rozvytok [Public administration: improvement and development], vol. 5, official site URL: http://www.dy.nayka.com.ua. [Ukraine]

4. Mandzinovska Kh.O. (2016) "Ekonomichna bezpeka derzhavy: sutnist, skladovi elementy ta problemy zabezpechennya" ["Economic security of the state: essence, constituent elements and problems of maintenance"], journal Naukovi zapysky [Scientific papers], vol. 2 (53), pp. 159-166 [Ukraine]

5. Pozdeyev V.L. (2016) "Osnovnyye napravleniya obespecheniya ekonomicheskoy bezopasnosti gosudarstva" ["The main directions of ensuring the economic security of the state"], journal Innovatsionnoye razvitiye ekonomiki [Innovative development of the economy], vol. 6-2 (36), pp. 270-276 [Russia]

6. Rohovyy A.V. (2020) "Determinanty zabezpechennya ekonomichnoyi bezpeky derzhavy" ["Determinants of economic security of the state"] Proceedings of the II International scientific and practical internet conference Problemy ta perspektyvy rozvytku finansovoyi systemy v suchasnykh umovakh [Problems and prospects of financial system development in modern conditions], Press PUET, Poltava. pp. 152-154.

7. Sazonov V.V. (2020) "Zovnishni zahrozy ekonomichniy bezpetsi derzhavy" ["External threats to the economic security of the state"], journal Nashe pravo [Our right], vol. 1, pp. 121-126 [Ukraine]

8. Sokolova H.B. (2018) "Deyaki aspekty rozvytku tsyfrovoyi ekonomiky v Ukrayini" ["Some aspects of digital economy development in Ukraine"], journal Ekonomichnyy visnyk Donbasu [Economic Bulletin of Donbass], vol. 1 (51), pp. 92-96 [Ukraine]

9. Shpilevskaya Ye.V. (2016) "Ekonomicheskaya bezopasnost strany: ugrozy i puti yeye obespecheniya" ["The economic security of the country: threats and ways to ensure"], journal Ekonomicheskiye nauki [Economic Sciences], vol. 5 (47), pp. 188-193 [Russia]

10. Dunning John H. (2000) The eclectic paradigm as an envelope for economic and business theories of MNE activity. International Business Review, Vol. 9. 163 p. [UK]

11. Khondker B.H. (2014) Economic Impacts of a Universal Pension in Bangladesh. Pathways' Perspectives on Social Policy, International Development. Vol. 17. P. 1-6. [UK]

12. McCormick David H., Luftig Charles E. and Cunningham James M. (2020) Economic Might, National Security, and the Future of American Statecraft (Summer 2020). Texas National Security Review: Vol. 3. Issue 3. P. 50-75 [USA] 